\title{
A CASE OF TESTICULAR TORSION DEMONSTRATED ON CONTRAST ENHANCED ULTRASOUND
}

\author{
Syed A. ', Pranay P. 2, Chua N. ', Naleem A. ', Mahmood I. ${ }^{3}$, Khan S. ${ }^{1}$
}

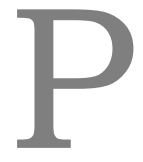

urpose. To demonstrate the potential of contrast enhanced ultrasound (CEUS) for the diagnosis of torsion taking the example of a man with equivocal clinical findings.

Materials and Methods. A 43 year old gentleman with no significant past medical history presented to the Accident and emergency following acute onset right testicular pain The clinical differential was of either epididymo-orchitis or testicular torsion.

Results. The patient underwent an ultrasound scan which revealed a normal left testicle but a swollen right testicle with no discernible flow on Doppler, thus raising the suspicion of acute torsion. To increase our confidence of the diagnosis the patient was immediately cannulated and a contrast enhanced ultrasound was performed. Within a few seconds, microbubbles could be seen within the parenchymal blood vessels in the left testicle as expected, however microbubbles could not be seen within the right testicle even after 5 minutes of scanning. The clinical team were informed of the findings and the patient was taken directly to theatre where testicular torsion was confirmed and orchidopexy was performed, preserving function of the right testicle.

Conclusions. In order to exclude testicular torsion, the imaging modality of choice which is used is ultrasound. torsion.

Keywords: ultrasound, contrast enhanced ultrasound, epididymo-orchitis, testicle

Corresponding author: Mahmood I, e-mail: dr_iftikhar@hotmail.com

For citation: Syed A., Pranay P., Chua N., Naleem A., Mahmood I., Khan S.. A case of testicular torsion demonstrated on contrast enhances ultrasound. REJR 2017; 7(4):161-163. DOI:10.21569/2222-7415-2017-7-4-161-163.

Статья получена: $\quad 22.09 .17 \quad$ Статья принята: $\quad 08.11 .17$

\section{АУЧЕВАЯ АИАГНОСТИКА ПЕРЕКРУТА ЯИЧКА С ПОМОЩЬЮ УАЬТРАЗВУКОВОГО ИССАЕАОВАНИЯ С ВНУТРИВЕННЫМ КОНТРАСТИРОВАНИЕМ}

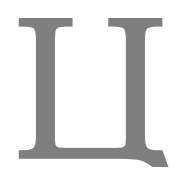

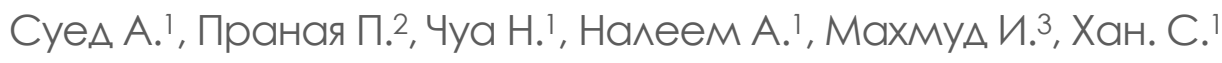

ель. Продемонстрировать потенциал ультразвукового исследования с внутривенным контрастированием в диагностике перекрута яичка.

Материалы и методы. Мужчина 43 мет поступил в госпиталь с жалобами на резкую боль в области правого яичка. Наследственный анамнез не отягощен. По клиническим признакам были поставлены предварительные диагнозы: орхоэпидидимис или перекрут яичка.

Результаты. Пациенту было выполнено ультразвуковое исследование, которое выявило увеличение и отёк правого яичка с отсутствием видимого кровотока, мевое яичко без особенностей. Таким образом, было выставлено предположение о наличии острого перекрута правого яичка. Дия уточнения диагноза пациенту бымо проведено умьтразвуковое исследование с внутривенным контрастированием. Через несколько секунд микровезикулы были видны в паренхиматозных кровеносных сосудах мевого яич-
1 - Basildon university hospital.

Essex, UK.

2 - Frimley Health NHS Trust. Surrey, UK.

3 - London northwest Healthcare NHS Trust. London, UK.
1 - Госпиталь Университета Базилдон. Эссекс, Великобритания. 2 - Отделение Национамьной смужбы здравоохранения Фримлей. Суррей,

Великобритания.

3 - Отдемение Национальной службы здравоохранения Аондона. Һондон, Великобритания. 


\section{RUSSIAN ELECTRONIC JOURNAL OF RADIOLOGY}

ка, что и должно определяться в норме. В области кровеносных сосудов правого яичка микровезикулы не визуализировались даже спустя 5 минут. Аечащий врач был информирован о находках при ультразвуковом исследованим и пациент был направлен в операционную, где диагноз перекрут правого яичка был подтвержден. Пациенту была выполнена операция орхидопексия, что позволило сохранить функция правого яичка.

Вывод. Дия подтверждения диагноза перекрута яичка методом выбора явцяется умьтразвуковое исследование.

Ключевые слова: ультразвуковое исследование, контрастное усимение при умьтразвуковом исследовании, орхоэпидидимис, перекрут яичка.

Контактный автор: Махмуд И., e-mail: dr_iftikhar@hotmail.com

Для иитирования: Суед А., Праная П., Чуа Н., Налеем А., Махмуд И.,Хан С.Аучева диагностика перекрута яичка с помошью ультразвукового исслеования с внутривенным контрастированием. REJR 2017; 7(4):161-163. DOI:10.21569/22227415-2017-7-4-161-163
Received:
22.09.17
Accepted:
08.11.17

$\mathrm{T}$

here are various signs on ultrasound which can help guide the operator as to whether a patient is suffering from testicular torsion.

The most important feature of the ultrasound examination is to compare the affected testes to the normal side, as any differences in the size, echotexture and vascularity would become apparent and help make the diagnosis (fig. 1, 2).

In $\mathrm{B}$ mode ultrasound, there are various signs which may be seen.

Torsion is caused by the hemiscrotum twisting around the spermatic cord on the affected side, and this can be seen as the whirlpool sign on moving the transducer down the testis [1].

Using a transverse image of both testes, the torted testis and epididymis will appear larger and have a more homogenous in echotexture than the normal testis, and this appearance itself is highly

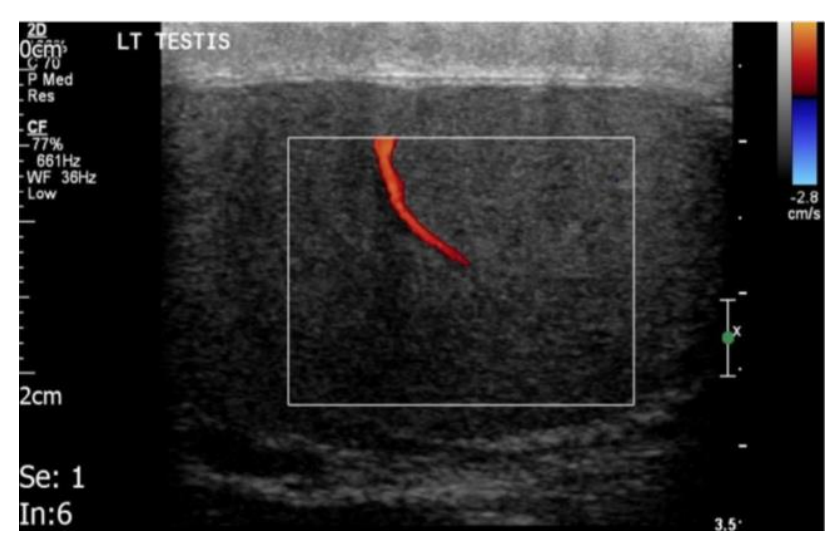

Fig. 1

Fig. 1. Ultrasound, B-mode.

Showing normal left testicle with flow on Doppler $101 \times 62 \mathrm{~mm}(300 \times 300 \mathrm{DPI})$. suspicious of acute torsion [2]. A heterogenous echotexture of the testis with hypoechoic regions would represent necrosis, and is a late sign of torsion, and may indicate a testis which can not be salvaged [2].

The scrotal wall can also become hyperaemic, and a reactive hydrocoele may be present in some cases [3].

In order to increase the sensitivity and specificity of ultrasound, Doppler can also be used [4].

When Doppler mode ultrasound is applied, to and fro flow may be seen with an elevated resistive index $(>0.75)$ in an incomplete torsion [1]. The absence of flow in the testis is a sign of complete torsion [2], this is best assessed on a transverse image when comparing it to the contralateral side, which will show normal flow. Torsion can cause the scrotal wall to become hyperaemic, this will easily be seen on Doppler imaging. Following the

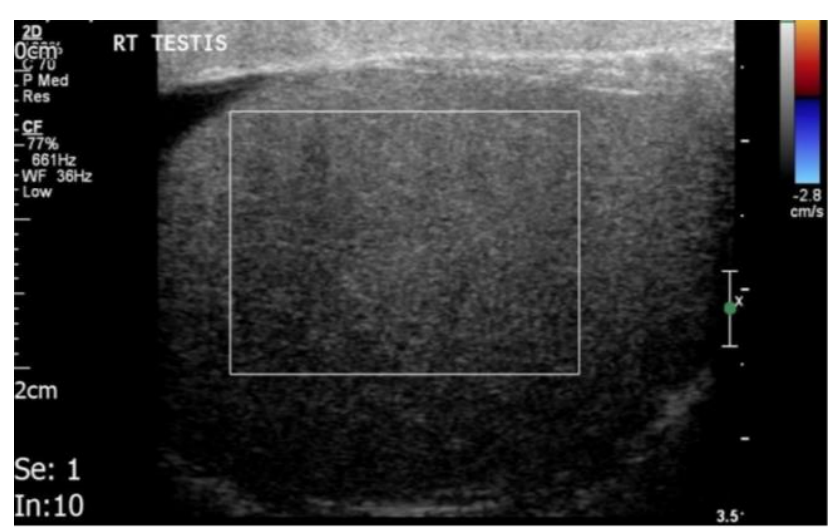

Fig. 2

Fig. 2. Ultrasound, B-mode.

Showing swollen right testicle with no flow on Doppler $104 \times 64$ mm (300x300 DPI). 
acute episode, collateral vessels can develop within the torted testis and peripheral testicular neovascularisation can be seen on Doppler imaging. In these cases there will only be patchy perfusion of the damaged testis [3].

The combination of all these signs helps B mode and Doppler ultrasound examinations diagnose testicular torsion.

Data shows that Doppler ultrasound can have a variable specificity for testicular torsion varying from as low as $46 \%$ [1] to as high as $97 \%$ [2] depending on various studies. In studies where Doppler and contrast enhanced ultrasound were

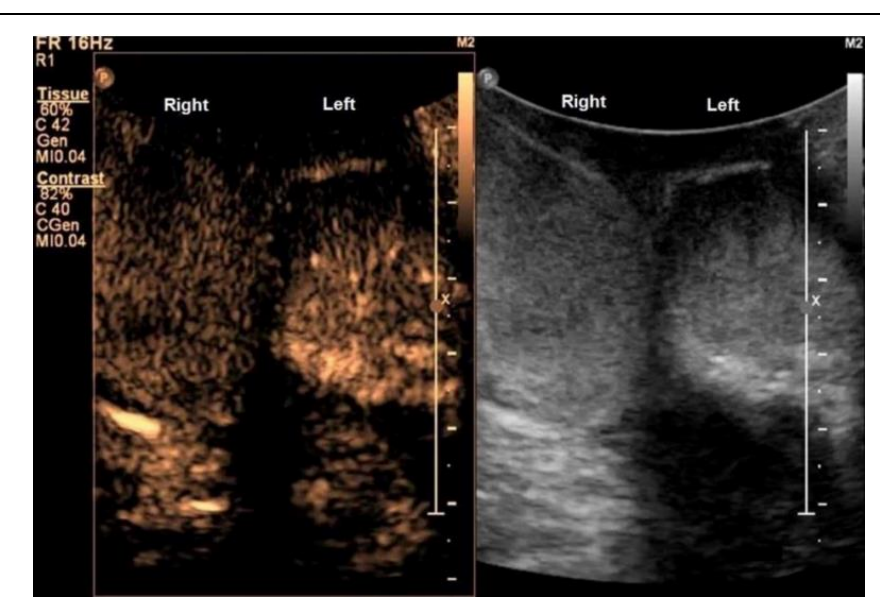

Fig. 3 a

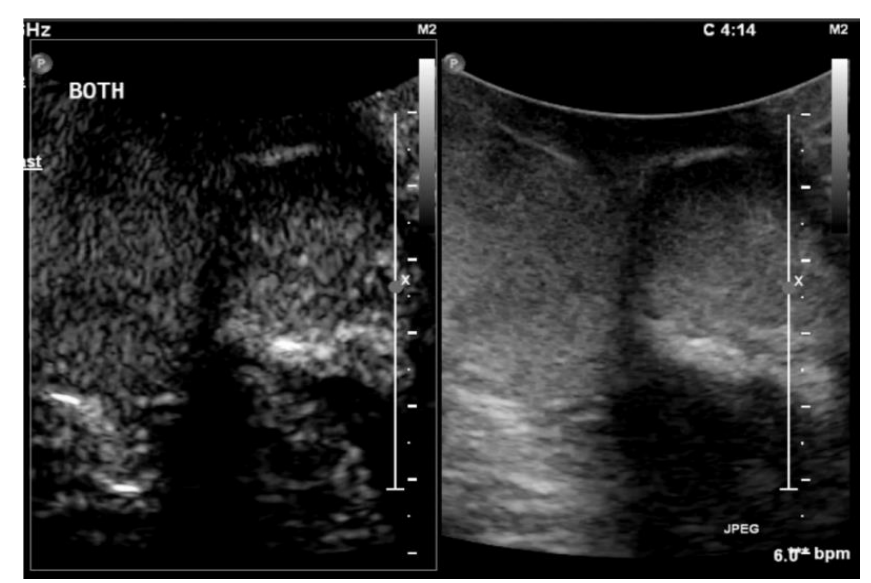

Fig. 3 c compared to each other in acute scrotal pathology, sensitivity and specificity were $76 \%$ and $45 \%$ for ultrasound and $96 \%$ and $100 \%$ for CEUS [3]. This case report demonstrates the viability of CEUS being used as a supplementary tool in the acute setting to increase the confidence in which acute torsion is suspected and therefore to prevent the patient undergoing unnecessary surgical exploration (fig.3).

Testicular Volumes [3, 4, 5]

Left $(4.1$ X $2.2 \times 2.6) \times 0.52=12.2 \mathrm{ml}$

$\operatorname{Right}(4.3 \times 2.8 \times 2.9) \times 0.52=18.2 \mathrm{ml}$.

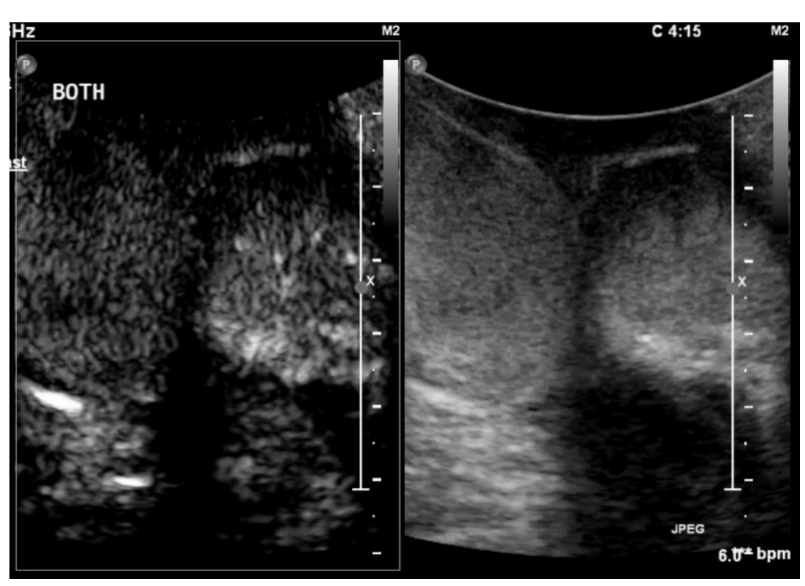

Fig. $3 \mathrm{~b}$

Fig. 3. Contrast enhanced ultrasound.

Image after 5 minutes showing absence of microbubbles in the right testicle compared to the normal appearance of the left testicle $100 \times 67 \mathrm{~mm}$ (300x300 DPI).

\section{References:}

1. Matemy J., Dymny M., Lesiewska L. et al. Assessment of the validity of Doppler sonography in the diagnosis of acute scrotum in boys. Pomeranian J Life Sci. 2015; 61 (2): 163-6.

2. Liang T., Metcalfe P., Sevcik W. et al. Retrospective review of diagnosis and treatment in children presenting to the paediatric department with acute scrotum. AJR Am J Roentgenol. 2013; 200 (5): W444-9. doi: 10.2214/AJR.12.10036.

3. Valentino M., Bertolotto M., Derchi L. et al. Role of contrast enhanced ultrasound in acute scrotal diseases. Eur Radiol. 2011; 21 (9): 1831-40. doi: 10.1007/s00330-010-2039-5.
4. Hamm B., Beyersdorff D., Asbach P. et al. Urogenital Imaging. George Thieme Verlag. 2008. ISBN:3131451513.

5. Bhatt S., Dogra V.S. Role of US in testicular and scrotal trauma. Radiographics. 2008; 28 (6): 1617-29.

6. Wolf K. Color duplex sonography, principles and clinical applications. Thieme. 1995. ISBN:0865775427.

7. Nussbaum Blask A.R., Bulas D., Shalaby-Rana E. et al. Color Doppler sonography and scintigraphy of the testis. Pediatr Emerg Care. 2002; 18 (2): 67-71. 